Debreceni Egyetem, Fogorvostudományi Kar, Bioanyagtani és Fogpótlástani Tanszék*

Debreceni Egyetem Fogorvostudományi Kar, Konzerváló Fogászati Tanszék ${ }^{\star \star}$

Debreceni Egyetem, Fogorvostudományi Kar, Általános Orvosi Ismeretek Tanszék ${ }^{\star \star \star}$

\title{
A fogászatban alkalmazható keresztkötött hialuronsav alapú hidrogélrendszerek szintézise és hatóanyag leadásának vizsgálata
}

\author{
Esetismertetés
}

RENTE TÜNDE*, DR. BAKÓ JÓZSEF*, DR. BÁGYI KINGA**, DR. JENEI ATTILA***, DR. HEGEDÜS CSABA*

\begin{abstract}
A hialuronsav biológiai lebonthatóságát, biokompatibilitását kiaknázva a hialuronsav alapú rendszerek alkalmazása egyre nagyobb teret kap a fogászatban is. A célzott hatóanyagszállítás megvalósítására az egyik legelterjedtebb eljárás a biopolimerek keresztkötése. Jelen munka célja olyan hialuronsavbázisú rendszerek előállítása és vizsgálata, amelyek a fogászatban is alkalmazható hatóanyag-leadó rendszerek alapjául szolgálhatnak. A különböző arányban $(25,50,75$, $100 \%$ ) térhálósított szerkezetek kialakítása a hialuronsav és a 2,2' (etiléndioxi)bisz(etilamin) kondenzációs reakciójával, karbodiimid felhasználásával történt. A részecskék méretének meghatározásakor a dinamikus lézer fényszórás fotometriai (DLS) mérések eredményeként megállapítható, hogy mind a négy módosított polimer trimodális méreteloszlást mutatott, továbbá, hogy a módosítás arányának növekedésével a részecskék mérete csökkent. A transzmissziós elektronmikroszkópos (TEM) felvételek szintén alátámasztják ezen eredményeket. A keresztkötött származékok hatóanyagleadó tulajdonságának jellemzése fotometriás méréstechnikával történt, modellvegyületként metilénkéket alkalmazva. Eredményeink azt bizonyították, hogy a keresztkötő ágens arányának növelésével a hatóanyag kioldódásának sebessége növekszik, amely a további kísérletekben egy új injektálható hatóanyag-kibocsátó rendszer fejlesztésének alapját képezheti.
\end{abstract}

Kulcsszó: hialuronsav, hidrogél, hatóanyag-kioldódás, keresztkötés, biokompatibilitás

\section{Bevezetés}

A hidrogéleket, természetes vagy szintetikus alapú polimereket nagy vízfelvevő képességüknek köszönhetően széles körben sikeresen alkalmazzák a regeneratív orvoslásban $[8,10]$. Az elmúlt években az injektálható hidrogélek megjelenésével terápiás lehetőség adódott antimikrobiális hatású szerek, bioaktív molekulák kontrollált felszabadítására és sejtek célzott alkalmazására $[1,14]$. A parodontális megbetegedések kezelésében különösen fontos lehet az antimikrobiális hatású szerek célzott és kontrollált hatásának szerepe, melyet hidrogélek segítségével optimalizáhatunk. Számos szisztémásan és lokálisan alkalmazott antimikrobiális terápiás protokollt dolgoztak ki, de a szisztémás antimikrobiális kezelés egyes esetekben nem képes elérni a hatékony minimális hatóanyag-koncentrációt a plazmában, például a korlátozott vérellátás miatt [20]. Szükséges volt a klinikai gyakorlatba bevezetni számos antifungális szert is, így például az újabb generációs azolokat és az echinocandinokat, mert a Candida fajok epidemiológiájában jelentős változások történtek [2224]. A biztonságos terápia érdekében nagyon fontos ezen anyagok megfelelő gátló koncentrációjának pontos meghatározása és célba juttatása [15]. Ezenkívül egyre nagyobb jelentőségük van a hidrogéllel alkotott kalcium-foszfát $\left(\mathrm{Ca}_{3}(\mathrm{PO} 4)_{2}\right)$ kompozitoknak, melyek nemcsak a csontregenerációra hatnak előnyösen, hanem a gél mechanikai tulajdonságait is javíthatják, és egyben a szövetrések kitöltésével önmagukban képesek háromdimenziós hálózatot (3-D) kialakítani, ezzel a kiültetett sejtek számára támasztékul is szolgálhatnak [1214]. A regeneratív endodonciában lehetővé válhat injektálható hidrogélekben a fogbél eredetű őssejtek szállíthatóságának megvalósítása [15-16]. Mátrixként történő alkalmazása, például növekedési faktorok (stroma eredetű növekedési faktor alfa-1 (SDF-1 $\alpha$ ), fibroblaszt növekedési faktor (FGF), és az odontogén, valamint a szöveti differenciálódás serkentésére alkalmas kulcsfontosságú csont morfogenetikus proteinek: BMP-2, BMP-7) szállítására ad lehetőséget, amely a dentin-fogbél komplex regenerálásának elősegítésére nyújthat hatékony megoldást [17-21].

A leggyakrabban használt szintetikus polietilén-glikol (PEG) alapú hidrogélekkel szemben a természetes növényi (alga) vagy állati eredetű hidrogélek előnyei közé tartozik az in vivo eredet, illetve, hogy napjainkban már ezek is elérhető áron és nagy mennyiségben állnak rendelkezésre. Biológiai karakterükből adódóan további előnyük, hogy nagy hasonlóságot mutatnak a na- 
tív extracelluláris mátrixhoz (ECM), illetve sem maguk, sem bomlástermékeik nem toxikusak és nem váltanak ki gyulladásos válaszreakciókat a szervezetben [17]. Felhasználási területeik között jelentős szerepet kap a sejtek vagy hatóanyagok szállítása, illetve ezeknek az alkalmazás területén történő szabályozott kibocsátása. Ennek egyik legegyszerübb esete, amikor a hatóanyagot egyenletesen eloszlatva belekeverik a kontrollált leadást végző hidrogél mátrixba. Az eloszlatott molekulák felszabadulásának sebessége és a hidrogélek fizikai paraméterei befolyásolhatók, a keresztkötések arányával, a felhasznált keresztkötő-anyagok, aktivációs ágensek mennyiségével, esetleg a kialakított anyag pórusméretének beállításával az igényekhez igazíthatók. A szabályozott hatóanyag-leadásra képes rendszerekkel elérhető a hatóanyag jelentétének elnyújtása és lokális koncentrációjának szabályozása. Ezen rendszerek megfelelő védelmet biztosíthatnak a tárolt hatóanyag inaktiválódása ellen, amely állandóan jelenlévő nehézség biológiai rendszerekben.

A természetes polimerek közül a hialuronsav (HA) az egyik legintenzívebben kutatott poliszacharid, amely az ECM egyik fő komponense a bőrben, a porcszövetben, és egyéb szervekben is fellelhető. Az ECM természetes makromolekuláris komponenseként biokompatibilis és több kötőhelyet is tartalmaz adhéziós molekulák számára. A HA fontos szerepet játszik a sebgyógyulásban, a regenerációban [7], és az embrionális őssejtek differenciációját, proliferációját és túlélését is támogatja [13]. A HA-oldat ugyanakkor szokatlanul magas viszkozitású és felületi feszültségű, így még alacsony koncentráció mellett is nehézkessé teszi az alkalmazását. A polimer oldat viszkozitása csökkentésének egyik legkézenfekvőbb módja a hialuronsav térhálósítása, melyet két vagy többfunkciós keresztkötő molekulák alkalmazásával, kémiai kötések kialakításával érhetünk el [2-5]. A módosítások során fontos törekedni arra, hogy az új, előnyös tulajdonságok kialakítását követően a szintetizált terméknek megmaradjon a biológiai aktivitása, és továbbra se váltson ki immunreakciót.

Az optimálisan kialakított HA-alapú gélek ígéretes mátrixként szolgálhatnak hatóanyagok célba juttatására. Fogászati mútéteket követően kialakult sebekre, illetve erek mellé helyezve alkalmazhatók különböző gyógyszermolekulák bejuttatására $[6,9,11]$. Ezen munka célja olyan különböző mértékben keresztkötött hialuronsav-diamin (HADA) rendszerek előállítása és vizsgálata, amelyek a jövőben akombinált, a fogászat területén is alkalmazható hatóanyag-leadó rendszerek fejlesztésének alapját képezhetik.

\section{Anyagok és módszerek}

A szintézis során felhasznált anyagok: hialuronsav Nasója (HA-Na, Mw = 1,63 × 10³ kDa), 2,2'(etiléndioxi)bisz (etilamin) (DA, Mw = 148,20 Da), 1-[3-(dimetil amino)pro- pil]-3-etil karbodiimid metil jodid (EDC, Mw = 191,70 Da), 1-hidroxibenzotriazol (HOBt, Mw = 135,12 Da). A kioldódásvizsgálatok során modellvegyületként metilénkéket (MK) alkalmaztunk. Minden vegyszer a SigmaAldrich Kft.-től (St. Louis, Egyesült Államok) került beszerzésre.

\section{Hialuronsav térhálósítása}

\section{2,2'(etiléndioxi)bisz(etilamin)-nal}

A különböző mértékben térhálósított $\mathrm{HA}$ előállításához DA-t alkalmaztunk keresztkötőként. A reakciókat vizes közegben, vízoldható karbodiimid (karboxilcsoport aktiválása) és benztriazol (racemizáció elkerülése) reaktánsok jelenlétében végeztük $2,5 \mathrm{mg} / \mathrm{ml}$ kiindulási polimer-koncentráció alkalmazásával, a pH-t 5,5 értékre beállítva, 24 óra reakcióidőt alkalmazva.

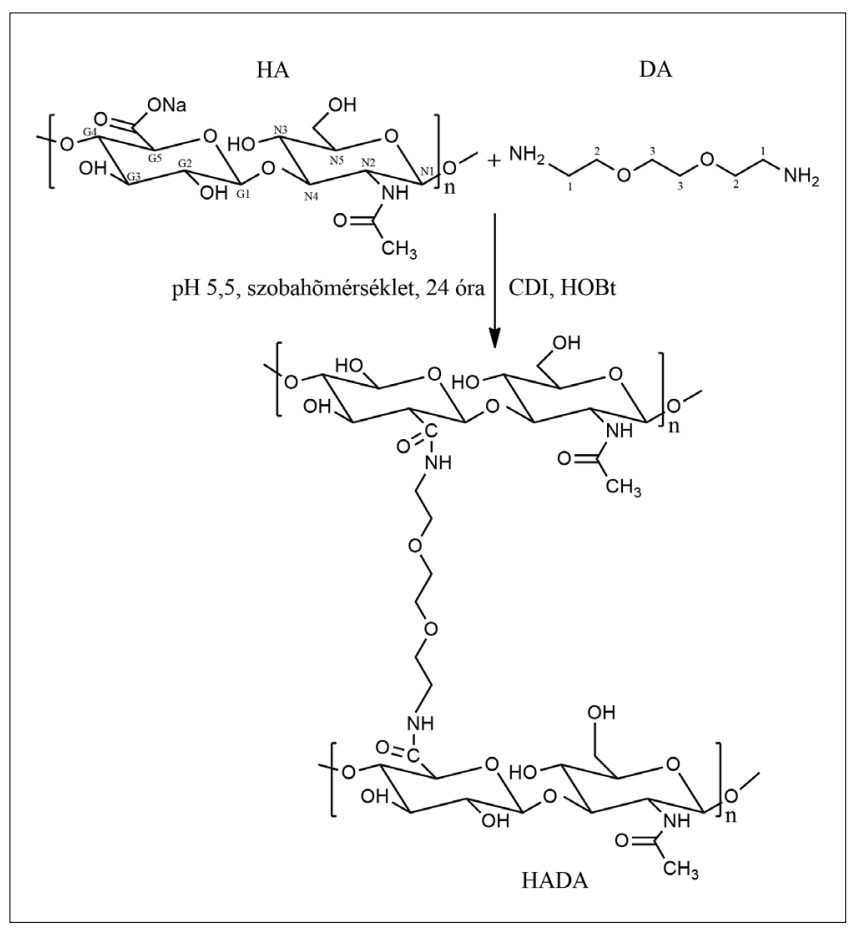

1. ábra: A hialuronsav $(\mathrm{HA})$

2,2'(etiléndioxi)bisz(etilamin)-nal (DA) történő térhálósításának mechanizmusa

A térhálósítási reakció paraméterei (az EDC, HOBt és a DA koncentrációk, illetve a keresztkötési arány) az 1. táblázatban szereplő adatok szerint kerültek kialakításra. A HADA25/50/75/100 hármas jelölésű rövidítésben, a HA kezdőbetűk a hialuronsavat, az azt követő DA betűk a diamint jelölik, míg a szám az elméleti keresztkötési rátára utal.

Az el nem reagált komponensek Vivaflow membránszűrővel (100 kDa PES) (Sartorius, Göttingen, Németország) kerültek eltávolításra. A szilárd anyag kinyerése liofilizálással (Christ Alpha 1-2 LD, Martin Christ Gefriertrocknungsanlagen $\mathrm{GmbH}$, Osterode am Harz, Németország) történt. 
A hialuronsav térhálósítási reakcióinak fő paraméterei.

\begin{tabular}{|c|c|c|c|c|c|}
\hline Hialuronsav $(\mathrm{mg})$ & $\begin{array}{c}\text { Térhálósítás } \\
\text { sztöchiometriai mértéke }(\%)\end{array}$ & Diamin $(\mu \mathrm{l})$ & EDC $(\mathrm{mg})$ & HOBt $(\mathrm{mg})$ & Jelölés \\
\hline 500 & 25 & 24 & 32 & 22 & HADA25 \\
\hline 500 & 50 & 48 & 64 & 44 & HADA50 \\
\hline 500 & 75 & 72 & 96 & 66 & HADA75 \\
\hline 500 & 100 & 96 & 128 & 88 & HADA100 \\
\hline
\end{tabular}

Térhálósított hialuronsav-származékok jellemzése A térhálós HA-származékok szerkezetének megállapítása ${ }^{13} \mathrm{C}$ mágneses magrezonancia $\left({ }^{13} \mathrm{C}\right.$-NMR) (Bruker 500SY, Bruker Daltonic GmbH, Németország) spektroszkópiai mérések segítségével történt. Az NMR-mérésekhez oldószerként deutérium-oxidot $\left(D_{2} O\right)$ használtunk. Referenciaanyagként tetra-metil-szilánt (TMS) $(\delta=0 \mathrm{ppm})$ alkalmaztunk, a vizsgált minta kémiai eltolódás (ס) értékei ennek a jeléhez lettek viszonyítva.

A polimer részecskék hidrodinamikai átmérőjének meghatározása dinamikus fényszórás (DLS, Dinamic Light Scattering) (BI-200SM, Brookhaven Instruments Corporation, New York, Egyesült Államok) fotométerrel történt. A hidrodinamikai átmérőt foton korrelációs spektroszkópia (PSC, Photon Correlation Spetrocsopy) elvén mértük és a Stokes-Einstein egyenlettel számoltunk:

$$
\mathrm{d}(\mathrm{H})=k T / 3 \pi \mu D,
$$

ahol: $d(H)=$ hidrodinamikai átmérō,

$D=$ transzlációs diffúziós együttható,

$\mathrm{k}=$ Boltzmann állandó, $\mathrm{T}=$ hőmérséklet és $\mu=$ viszkozitás.

A mérési eredmények értékelése az NNLS (non negative constrained least squares/legkisebb négyzetek) módszerrel történt.A szilárd állapotú részecskék méretének és morfológiájának meghatározása transzmiszsziós elektronmikroszkóppal (TEM) (JEOL 2000 FX-II, Jeol Ltd., Akishima, Japán) készített felvételek alapján történt. A minták vizsgálata szénréteggel bevont G2400C típusú rézhálón történt, a gyorsítófeszültség $80 \mathrm{kV}$ volt.

Az in vitro kioldódási dinamika tanulmányozására modellvegyületként a széles körben alkalmazott MK-et használtuk. A vizsgálat 12 lyukú platebe helyezett, $0,4 \mu \mathrm{m}$ pórusméretű, PET sejttenyésztő betétben (Millicell, Merck KGaA, Darmstadt, Németország), folyamatos rázatás (100 RPM) mellett (NB-205 síkrázó inkubátor, N-Biotek Co., Ltd., Gyeonggi-do, South Korea) szobahőmérsékleten, ötnapos vizsgálati periódus meghatározásával valósult meg. Először az $1 \mathrm{mg} / \mathrm{ml}$-es MKoldatot készítettük el, majd az $1 \mathrm{~m} / \mathrm{m} \%$-os géloldatokat (HA, HADA25/50/75/100) a MK-et tartalmazó oldat felhasználásával, $10 \mathrm{~m} / \mathrm{m} \%$-os MK koncentrációt kalkulálva az egyes gélekre, majd minden betétbe $10 \mathrm{mg}$ minta került bemérésre. A MK leadásának nyomon követésére spektrofotometriás módszert (Hidex, Turku, Finnor- szág) alkalmaztunk. Oldószerként/ duzzasztószerként és kioldóközegként $(2 \mathrm{ml})$ ioncserélt vizet használtunk. Minden mintavételi pontban a teljes kioldóközeg lecserélésre került. A spektrofotometriás mérés $661 \mathrm{~nm}$-en történt.

\section{Eredmények}

Az előállított anyagok vizsgálatai azt mutatták, hogy sikerült különböző mértékben térhálósított hialuronsavszármazékokat létrehozni. Térhálósítóként egy hosszabb szénláncú diamint választottunk, mellyel a térhálósítás mértékének a növelését kívántuk elősegíteni, illetve a reakció számított (sztöchiometriai) és valós mértékének a közelítését. A térhálósítás során a HA karboxilcsoportjai reagálnak a térhálósító DA amino-csoportjaival kovalens savamid/peptid kötést képezve. A szintézist karbodiimid és benztriazol aktiváló ágensekkel egészítettük ki. A keletkező térhálós szerkezet tanulmányozása NMR spektroszkópiával történt. A HA és a 100\%ban térhálósított nanorészecske (HADA100) ${ }^{13} \mathrm{C}-\mathrm{NMR}$ spektrumainak összehasonlítása során a kémiai jelek eltolódása, valamint a keresztkötő diaminra jellemző jelek jól azonosíthatók. A térhálósított származék spektrumában megjelenő, a diaminra jellemző kémiai eltolódások ( $\delta=67,54(\mathrm{C} 1), \delta=70,33(\mathrm{C} 2), \delta=40,04(\mathrm{C} 3)$ )

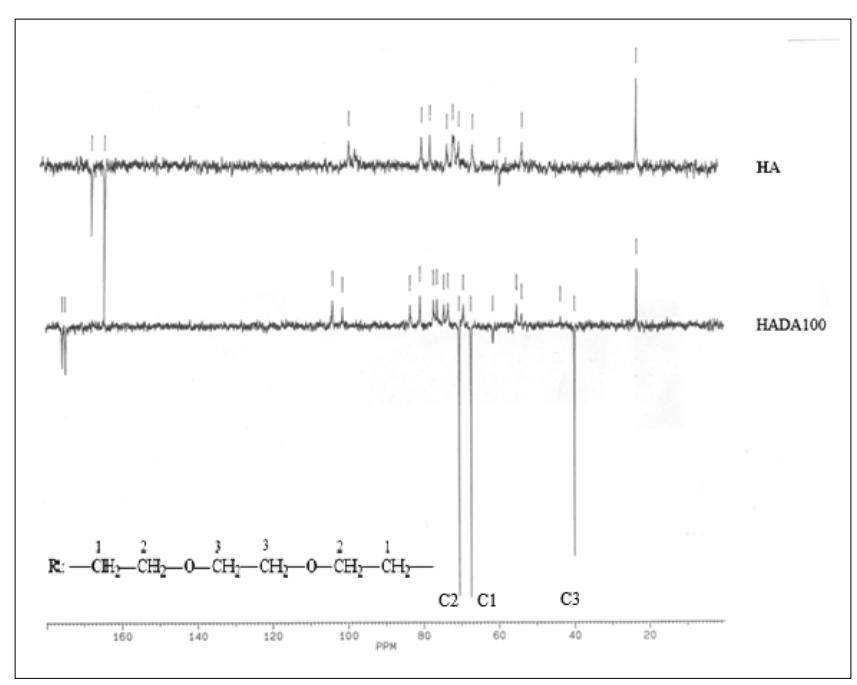

2. ábra: A hialuronsav (HA)

és az elméletileg 100\%-ban keresztkötött hialuronsav (HADA100) ${ }^{13} \mathrm{C}$-NMR spektrumainak összehasonlítása 


\section{2. táblázat}

A térhálós hialuronsav-részecskék effektív hidrodinamikai átmérői

\begin{tabular}{|c|c|c|c|}
\hline Térhálósítás mértéke $(\%)$ & 1. csúcs $(\mathrm{nm})$ & 2. csúcs $(\mathrm{nm})$ & 3. csúcs $(\mathrm{nm})$ \\
\hline 25 & $195 \pm 25$ & $585 \pm 40$ & $1730 \pm 65$ \\
\hline 50 & $146 \pm 20$ & $350 \pm 25$ & $1458 \pm 80$ \\
\hline 75 & $108 \pm 10$ & $254 \pm 20$ & $1026 \pm 70$ \\
\hline 100 & $74 \pm 15$ & $126 \pm 15$ & $785 \pm 65$ \\
\hline
\end{tabular}

bizonyítják a reakció sikeres végbemenetelét. Ez mutatja, hogy a peptidszintézisek révén ismertté vált technika hatékonyan alkalmazható a HA módosítására, térhálósítására is.

\section{DLS eredmények}

A térhálós nanorészecskék hidrodinamikai átmérőjét fényszórás fotometriával határoztuk meg vizes közegben, $\mathrm{pH}=7,0$ és $100 \mu \mathrm{g} / \mathrm{ml}$ koncentráció mellett. Az eredmények a 2. táblázatban kerültek bemutatásra.

A fényszórás fotometriai mérési eredmények a keresztkötött $\mathrm{HA}$ részecskék trimodális eloszlását mutatják. A HA keresztkötései, intra- és intermolekuláris kapcsolódási lehetőségeket eredményezhettek, így a HADA részecskék egy része kisméretü, különálló részecskékké formálódhattak, ugyanakkor nagyobb részecskék keletkezésére is lehetőség nyílhatott. Mindemellett nagyobb részecskék aggregáció következtében is keletkezhettek, másodlagos kötőerők, illetve intermolekuláris köl-

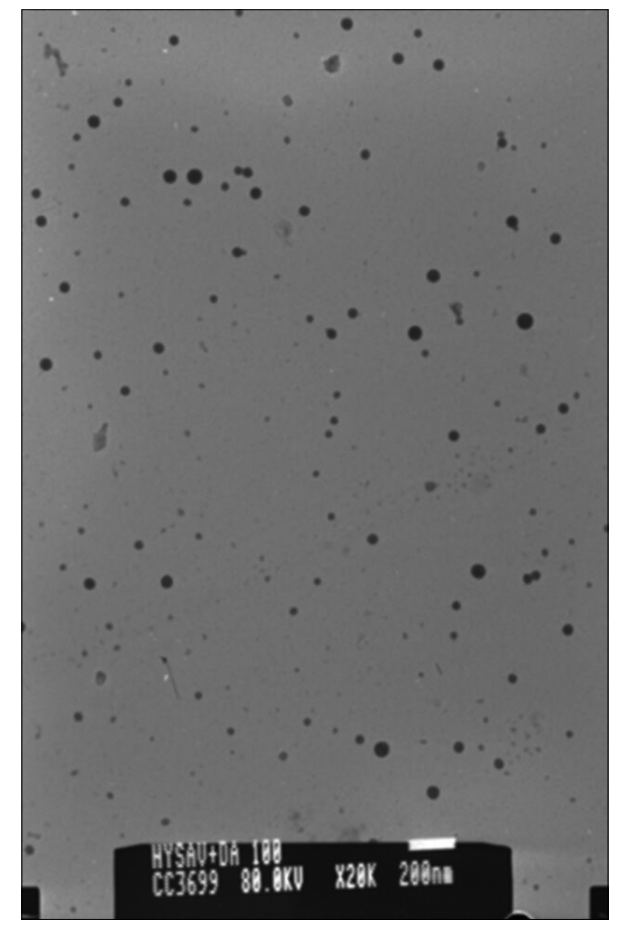

3. ábra: A 100\%-ban keresztkötött hialuronsav (HADA100) TEM felvétele (20000-szeres nagyítás, lépték 200 nm) csönhatások következtében. Mivel a reakcióelegy nanorészecskéinek hidrodinamikai átmérője nem egységes, ezért a Z-átlagot alkalmaztuk a kialakult mérettartományok összehasonlításához. A térhálós hialuronsav-részecskék (HADA25/50/75 és 100) effektív hidrodinamikai átmérőinek eredményeit összevetve megállapítható, hogy a térhálósítás mértékének növelésével csökken a részecskék hidrodinamikai mérete, egyre kompaktabb részecskék keletkeznek.

\section{TEM eredmények}

A HA térhálósításával különálló gömbszerū részecskéket kívántunk előállítani. A TEM felvételek alkalmasak a kialakított polimerek méretének és formájának az igazolására. A 3. ábrán bemutatott TEM-felvétel bizonyítja, hogy a 100\%-ban keresztkötött, szilárd halmazállapotú, térhálós szerkezetű polimer (HADA100) kisméretü, jól diszpergált nanorészecskék formájában jelenik meg, melynek mérete $20 \mathrm{~nm}$ alatt van.

A különböző térháló-sűrűségű hidrogélek kioldódási tulajdonságai

A 4. ábra a HA-alapú gélek, valamint a gél nélküli MK-oldat membrándiffúziós vizsgálata során nyert kioldódási profilokat mutatja be.

A vizsgálatok a megbízható eredmények érdekében mintatípusonként 3 párhuzamos méréssel kerültek kivitelezésre. A hatóanyag-leadó sajátságokat mind a négy

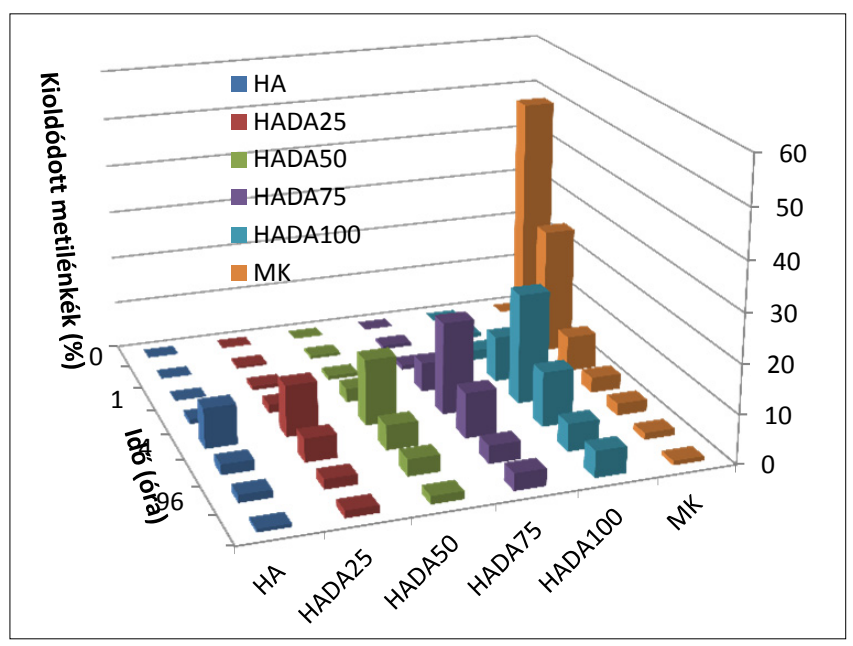

4. ábra: A hialuronsav (HA),

a különböző mértékben keresztkötött származékok (HADA 25/50/75/100)

és metilénkék (MK) kioldódási profiljai (SD: 0,002-0,014) 
(HADA25/50/75/100) keresztkötött származék, a módosítás alapját képző HA és a MK-oldat, mint a kontroll minták esetében is vizsgáltuk. Azt tapasztaltuk, hogy a vizsgálat során az összes kioldódó anyag mennyisége a térhálósürüség emelkedésével párhuzamosan emelkedik, míg a HADA25 esetén $15,2 \%$, a HADA50 mintánál $28,0 \%$, a HADA75-nél 42,6\%, addig a HADA100 polimer esetében már $57,6 \%$ hatóanyag oldódott ki.

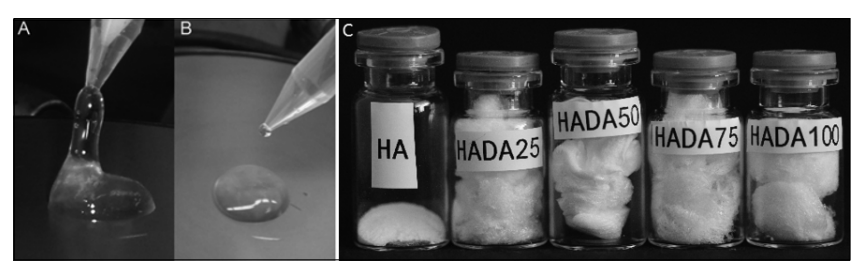

5. ábra: (A) a kiindulási hialuronsav,

és (B) a 100\%-ban keresztkötött hialuronsav-vizes oldata (c = $10 \mathrm{mg} / \mathrm{ml}$ ), (C) a hialuronsav és különböző mértékben keresztkötött származékok fizikai magjelenése liofilizálást követően, szilárd állapotban

\section{Megbeszélés}

A szintetizált hialuronsav-származékokkal elvégzett vizsgálatok azt mutatják, hogy sikerült kovalens kötéseken keresztül térhálós szerkezetű részecskéket előállítani. A nanorészecskéket közvetlenül a lineáris polimer reaktív karboxil-csoportján keresztül kétfunkciós homoaminodimerrel mint kapcsoló ágens alkalmazásával, amidkötések kialakításán keresztül valósítottuk meg. A kiindulási és a módosított vegyületek ${ }^{13} \mathrm{C}-\mathrm{NMR}$ spektrumai igazolták, hogy a hialuronsav karboxilcsoportjai a diamin aminocsoporjaival savamid kötést létesítenek, és ezeken keresztül alakítanak ki kémiai térhálót. A keresztkötő ágensre jellemző karakterisztikus kémiai eltolódású jelek a spektrumon $\delta=67,54(C 1)$, $\delta=70,33$ (C2), $\delta=40,04$ (C3) ppm-nél egyértelmüen azonosíthatók. A képződött térhálós részecskék száraz állapotban megjelenő nano-mérettartományát a TEMvizsgálatok igazolták. Az oldatbeli duzzadt részecskék méreteire és trimodális részecskeméret-eloszlására pedig a DLS-mérések nyújtottak bizonyítékot. Mindezen jelenségek a térhálósodás során bekövetkező intra- és inter-molekuláris kötődési lehetőségekkel, valamint láncvégi savamidkötések megjelenésével magyarázhatók, valamint az aggregátumok kialakulását sem zárhatjuk ki. A hidrodinamikai átmérők eredményeiből megállapítható, hogy az egyre növekvő térhálósítási arány egyre kisebb méretú részecskék keletkezését eredményezte.

Megállapítható, hogy a térhálósítás arányának növelésével a hatóanyag-leadás sebessége nő, amely a módosított polimerek megváltozott fizikai tulajdonságaiból eredeztethető. Ilyen hatásként tekinthetünk esetleg a térhálósítás növelésével csökkenő vízfelvevő képességre, a térhálósabb részecske kisebb méretére, azok kompaktabb szerkezetére, aminek következtében eset- legesen kevésbé tud immobilizálódni a festékmolekula, vagy arra, hogy a fajlagos felülettel párhuzamosan nő a kioldódás sebessége, esetleg a polimer által koordinált hidrátburok is befolyással lehet a kioldódás sebességére. A különböző hatások érvényesülésének/ versengésének eredményeként kompromisszumokat kell tenni a hidrogélek tervezésekor a célzott alkalmazást illetően a polimer-hatóanyag eltérő affinitásának ismeretében [19]. Az előállított rendszer várhatóan injektálható polimeroldatként kerülhet alkalmazásra mint hatóanyag szállítására és leadására képes eszköz. A részecskék szerkezetükből adódóan alkalmasak lehetnek hatóanyagok szabályozott kibocsátására. A térhálósítás mértékének változtatásával a nanorészecskék mérete, pórushálózata a felhasználási igények szerint változtatható, így ezáltal a fogászatban is jól hasznosítható hatóanyag-leadó rendszer kialakítására nyílhat lehetőségünk.

\section{Köszönetnyilvánítás}

A kutatás a TÁMOP-4.2.2.A-11/1/KONV-2012-0036 azonosító számú Nemzeti Kiválóság Program-Intelligens funkcionális anyagok: mechanikai, termikus, elektromágneses, optikai tulajdonságaik és alkalmazásaik címú kiemelt projekt keretében zajlott. A projekt az Európai Unió támogatásával, az Európai Szociális Alap társfinanszírozásával valósult meg.

\section{Irodalom}

1. Allison DD, Grande-Allen KJ: Review. Hyaluronan: a powerful tissue engineering tool. Tissue Eng. 2006; 12: 2131-2140.

2. Aulin C, Bergman K, Jensen-Waern M, Hedenqvist P, Hilborn J, ENGSTRAND T: In situ cross-linkable hyaluronan hydrogel enhances chondrogenesis. J Tissue Eng Regen Med. 2011; 5: 188-196.

3. Aulin C, Lundbäck P, Palmblad K, Klareskog L, ERlandsson Harris $\mathrm{H}$ : An in vivo cross-linkable hyaluronan gel with inherent anti-inflammatory properties reduces $O A$ cartilage destruction in female mice subjected to cruciate ligament transection. Osteoarthritis and Cartilage. 2017; 25: 157-165.

4. Chunhong Luo, Jianhao Zhao, Mei Tu, Rong Zeng, Jianhua Rong: Hyaluronan microgel as a potential carrier for protein sustained delivery by tailoring the crosslink network. Materials Science and Engineering. 2014; 36: 301-308.

5. Martinez-Sanz E, Varghese OP, Kisiel M, Engstrand T, Reich KM, BOHNER M: Minimally invasive mandibular bone augmentation using injectable hydrogels. J Tissue Eng Regen Med. 2012; 6: 3.

6. Fraser R, Laurent TC, Laurent UB: Hyaluronan: its nature, distribution, functions and turnover. J Intern Med. 1997; 242: 27-33.

7. FRENKEL JS: The role of hyaluronan in wound healing. Int Wound J. 2014; 11: 159-163.

8. Hoffman AS: Hydrogels for biomedical applications. Adv Drug Deliv Rev. 2002; 54: 3.

9. Bergman K, Engstrand T, Hilborn J, Ossipov D, Piskounova S BOWDEN T: Injectable cell-free template for bone-tissue formation. J Biomed Mater Res Part A. 2009; 91: 1111-1118.

10. Kucera L, Weinfurterova R, Dvorakova J, Kucera J, Pravda M, Foglarova $M$, et al.: Chondrocyte Cultivation in HyaluronanTyramine Cross-Linked Hydrogel. Int J Polym Mater. 2015; 64: 661-674. 
11. LuO Y, KIRKER KR, Prestwich GD: Cross-linked hyaluronic acid hydrogel films: new biomaterials for drug delivery. $J$ Control Release. 2000; 69: 169-184.

12. Park SJ, Li Z, Hwang IN, Huh KM, Min K-S: Glycol Chitinbased Thermoresponsive Hydrogel Scaffold Supplemented with Enamel Matrix Derivative Promotes Odontogenic Differentiation of Human Dental Pulp Cells. J Endod. 2013; 39: 10011007.

13. PRESTON M, SHERMAN LS: Neural Stem Cell Niches: Critical Roles for the Hyaluronan-Based Extracellular Matrix in Neural Stem Cell Proliferation and Differentiation. Front Biosci (Schol Ed). 2011; 3: 1165-1179.

14. Prestwich GD: Engineering a clinically-useful matrix for cell therapy. Organogenesis. 2008; 4, 42-47.

15. Segura T, Anderson BC, Chung PH, Webber RE, Shull KR, Shea LD: Crosslinked hyaluronic acid hydrogels: a strategy to functionalize and pattern. Biomaterials. 2005; 26: 359-371.

16. Shu Xz, Liu Y, Luo Y, Roberts Mc, PREStwich GD: Disulfide crosslinked hyaluronan hydrogels. Biomacromolecules. 2002; 3: 13041311.

17. Stevens MM, George HJ: Exploring and Engineering the Cell Surface Interface. Science. 2005; 310: 1135-1138.
18. Suzuki T, Lee CH, Chen M, Zhao W, Fu SY, Qı JJ: Induced Migration of Dental Pulp Stem Cells for in vivo Pulp Regeneration. J Dent Res. 2011; 90: 1013-1018.

19. Todd RH, Daniel SK: Hydrogels in drug delivery: Progress and challenges. Polymer. 2008; 49: 8.

20. Тон WS, Spector M, Lee EH, CaO T: Biomaterial-Mediated Delivery of Microenvironmental Cues for Repair and Regeneration of Articular Cartilage. Mol Pharm. 2011; 8: 994-1001.

21. TOOLE BP: Hyaluronan: from extracellular glue to pericellular cue. Nat Rev Cancer. 2004; 4: 528-539.

22. Varga I, Sóczó G, Kardos G, Kemény-Beke A, Kelentey B, Márton I és mtsai. Differences in killing activity of caspofungin and paradoxical growth between $\mathrm{C}$. albicans and $\mathrm{C}$. krusei clinical isolates in different media. J Chemother. 2009; 36-41.

23. Varga I, Sóczó G, Kardos G, Borbély A, Szabó Z, Kemény-Beke A: Comparison of killing activity of caspofungin against Candida parapsilosis, Candida orthopsilosis and Candida metapsilosis. $J$ Antimicrob Chemother. 2008; 62: 1466-1468.

24. Varga I, Sóczó G, Kardos G, Majoros L: Time-kill studies investigating the killing activity of caspofungin against Candida dubliniensis: comparing RPMI-1640 and antibiotic medium 3. J Antimicrob Chemother. 2008; 62: 149-152.

Rente T, Bakó J, Bágy K, Jenei K and Hegedüs Cs

\section{Preparation and drug profile analysis of crosslinked hydrogels based on hyaluronic acid for dental application}

Exploiting the biodegradability and biocompatibility of hyaluronic acid, the hyaluronic acid-based systems are increasingly used in dentistry also. To achieve the targeted drug delivery one of the most widely used method of cross-linking the biopolymers. The purpose of this work was to produce and characterizes hyaluronic acid-based systems, which can also be used in dentistry as drug delivery system. To synthesize the different ratios $(25,50,75,100 \%)$ cross-linked structure hyaluronic acid sodium salt and 2,2'(ethylenedioxy) bis (ethylamine) was applied in a condensation reaction using carbodiimide. The sizes of the particles were determined by dynamic light scattering (DLS) measurements. On the basis of the results obtained that each of four kinds of modified material are made up three different particle sizes and when the rate of change was increased, the particle size was decreased. This could be compared to results obtained under transmission electron microscope (TEM) investigations. To characterize the release behavior of cross-linked derivatives of hyaluronic acid, photometric measurement technique was applied using methylene blue as a model compound. Our results supported that the proportion of cross-linking was increased, the drug release rate was increased also, which may be the basis for further experiments in the development of a new injectable drug substance issuer system.

Keywords: hyaluronic acid, hydrogel, drug delivery, crosslinking, biocompatibility 